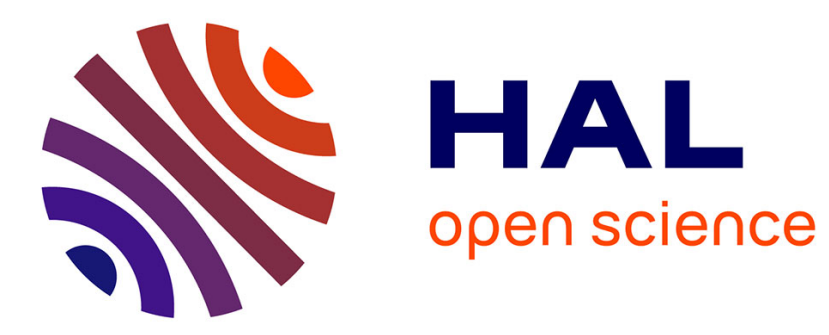

\title{
A cross-cultural perspective on feeling good in the context of foods and beverages
}

Claire Sulmont-Rossé, Rafal Drabek, Valérie L. Almli, Hannelize van Zyl, Ana Patricia Silva, Martin Kern, Jean A Mcewan, Gastón Ares

\section{- To cite this version:}

Claire Sulmont-Rossé, Rafal Drabek, Valérie L. Almli, Hannelize van Zyl, Ana Patricia Silva, et al.. A cross-cultural perspective on feeling good in the context of foods and beverages. Food Research International, 2019, 115, pp.292-301. 10.1016/j.foodres.2018.12.012 . hal-02628434

\section{HAL Id: hal-02628434 \\ https://hal.inrae.fr/hal-02628434}

Submitted on 4 Feb 2021

HAL is a multi-disciplinary open access archive for the deposit and dissemination of scientific research documents, whether they are published or not. The documents may come from teaching and research institutions in France or abroad, or from public or private research centers.
L'archive ouverte pluridisciplinaire HAL, est destinée au dépôt et à la diffusion de documents scientifiques de niveau recherche, publiés ou non, émanant des établissements d'enseignement et de recherche français ou étrangers, des laboratoires publics ou privés. 


\section{A cross-cultural perspective on feeling good in the context of foods and beverages}

Claire Sulmont-Rossé ${ }^{*}$, Rafal Drabek ${ }^{2}$, Valérie L. Almli ${ }^{3}$, Hannelize van Zyl ${ }^{4}$, Ana Patricia Silva ${ }^{5}$, Martin Kern ${ }^{6}$, Jean A McEwan ${ }^{7}$, Gastón Ares ${ }^{8}$

${ }^{1}$ Centre des Sciences du Goût et de l'Alimentation, AgroSup Dijon, CNRS, INRA, Université Bourgogne Franche-Comté, F-21000 Dijon, France

${ }^{2}$ ACCE International, 2575 Dunwin Drive, Mississauga, Ontario L5L 3N9, Canada

${ }^{3}$ Nofima AS, PO Box 210, 1431 Ås, Norway

${ }^{4}$ HEINEKEN Global Innovation and Research, Burg. Smeetsweg 1, 2382 PH Zoeterwoude, The Netherlands,

${ }^{5}$ Universidade Católica Portuguesa, CBQF - Centro de Biotecnologia e Química Fina - Laboratório Associado, Escola Superior de Biotecnologia, Rua Arquiteto Lobão Vital, apartado 2511, 4202-401 Porto, Portugal. [Current Address: Eurofins SAM Sensory and Marketing, Spain]

${ }^{6}$ Eurofins SAM Sensory and Marketing International GmbH, Germany

7 Jean A McEwan Consulting Ltd, UK

${ }^{8}$ Sensometrics \& Consumer Science, Instituto Polo Tecnológico de Pando, Facultad de Química, Universidad de la República, Uruguay

* Corresponding author: Claire Sulmont-Rossé, CSGA-INRA, 17 rue Sully, BP 86510 , 21065 Dijon Cedex, France; claire.sulmont-rosse@inrae.fr 


\section{Abstract}

The aim of the present research was to explore consumers' conceptualization of feeling good in relation to food and beverages from a cross-cultural perspective. Participants from 14 countries across 5 continents and covering 10 languages $(N=8,325)$ responded to an online survey including word association and free listing tasks related to feeling good in the context of food and beverages. Results were analyzed using inductive coding: a list of main codes was generated in English for each of the tasks, after which native speakers for each language coded the responses. Codes were grouped into categories reflecting common themes from which eight dimensions were identified. Results showed that in the context of foods and beverages, feeling good was mainly associated with specific foods and sensory and hedonic properties. Across the 14 countries, 'Sweet and fat food', 'Fruit and vegetables', and 'Protein food' were the three food categories most associated with feeling good. Emotional aspects of food consumption ('Taste good' and emotions) were also relevant. Health and nutrition-related aspects were more relevant for consumers when they were asked to think about how foods and beverages would make them feel good in the future. In other words, food-related feeling good seems to be mainly driven by sensory pleasure at present, but it is also related to nutrition and health in the future. Differences in the strength of the associations between feeling good and the identified categories were found between countries, in line with the existence of cultural differences in food habits, as well as in the importance people attach to the characteristics of foods and beverages. Results from the present work provide insights on the impact of eating and drinking on feeling good in terms of emotional, physical and social aspects, and increase knowledge about the way food and drink can contribute to general well-being.

\section{Keywords}

Feeling good; Food; Eating; Word association; Emotion; Cross-cultural comparison; Well-being;

\section{Highlights}

- In a food-related context, feeling good is a multi-dimensional construct.

- Feeling good is strongly associated with hedonic aspects of food consumption.

- Health and nutrition gain in salience when thinking of feeling good in the future.

- There are cultural differences in the conceptualization of feeling good. 


\section{Introduction}

Interest in understanding how food and beverages contribute to perceived well-being has increased rapidly in recent years (Meiselman, 2016). Well-being has been identified as a key construct for obtaining a more in-depth understanding of consumers' food choices and has been increasingly recognized in the development of more effective public policies and interventions for encouraging healthy eating (Bock et al., 2014; EU, 2014; FAO, 2015; WHO, 2018). Well-being is also increasingly used in the marketing strategies of the food and beverage industry, as several companies promote the merits of their products on well-being. Despite this growing interest, well-being still lacks a clear definition (Dodge et al., 2012), and has been conceptualized as:

- A positive construct (Aubert, 2017). Well-being has been associated with positive feelings and the absence of negative feelings.

- A subjective construct (Diener et al., 2009). Well-being has been strongly associated to subjective evaluation of how each person evaluates his/her own life.

- A multi-dimensional construct (Meiselman, 2016). Well-being has been conceptualized as the balance of five (sometimes more) dimensions, including physical, emotional, social, intellectual and spiritual dimensions (Hettler, 1984; Veenhoven, 2000; Diener et al., 2003; King et al., 2015).

Several questionnaires have been designed to define and measure well-being. In their systematic literature review, Lindert et al. (2015) identified 60 unique measurement tools. These authors reported that "measurement scales were either multidimensional $(n=33)$ or unidimensional $(n=14)$ and assessed multiple domains. The most frequently encountered domains were affects (39 scales), social relations (17 scales), life satisfaction (13 scales), physical health (13 scales), meaning/achievement ( 9 scales) and spirituality (6 scales)." It is interesting to note that these methods seldom use the specific term "well-being" (WHO Regional Office for Europe, 2012). Instead, they include subjective items related to "feeling good" (Bech, 1993) and "satisfaction with life" (Diener et al., 1985; EuroQol Group, 1990), or objective items related to economic, social and environmental characteristics (Mezzich, 2011; WHO, 1997). For instance, the WHO Well-being Index (Bech, 1993) includes five items all related to positive feelings ("I have felt cheerful and in good spirits"; "I have felt calm and relaxed"; "I have felt active and vigorous"; "I woke up feeling fresh and rested"; "My daily life has been filled with things that interest me").

As evidence by the review of Lindert et al. (2015), positive feelings are an important dimension of well-being. Emotions have been recognized as a key determinant of wellbeing by Diener et al. (2009), who conceptualized this construct as the extent to which people feel positive emotions and do not feel unpleasant emotions. Recent studies suggest that this is even true when investigating well-being in relation to food and beverages. Ares et al. (2015) reported that affects (pleasure, happiness, enthusiasm, satisfaction and peace/calm) were the most relevant associations when consumers in five countries (Brazil, France, Portugal, Spain and Uruguay) were asked to write down the first words that came to their mind when thinking of well-being. Guillemin et al. (2016) conducted several discussion groups with healthy and non-healthy French participants to explore the experience of well-being in the context of food and diet. Results highlighted that well-being was associated with two main dimensions: well- 
being related to pleasure (e.g., tasting good, having the choice, sharing, new flavors) and well-being related to health (e.g., varied diet, organic produce, healthy diet, eating in moderation). In the context of product development, King et al. (2015) have developed the WellSense profile to measure food-induced wellness. This profile includes 45 emotions among which 35 were positive (e.g., clam, happy, satisfied, grateful, energetic, fulfilled). In developing The Eating Motivation Survey (TEMS), Renner and collaborators (Renner et al., 2012) identified 15 motivations for eating what we eat, including physical (need \& hunger, health, weight control), sensory and hedonic (liking, pleasure, visual appearance), emotional (affect regulation), social (sociability, social norms and social image), habitual (habits, traditional eating), practical (price, convenience) and natural (natural concern) aspects, all of which have the potential to trigger positive feelings if satisfying our expectations and needs.

In this context, the aim of the present experiment was to investigate the concept of "feeling good" in a food-related context. In fact, eating and drinking are frequent daily events that have the potential of making us feel good in terms of satiation, sensory satisfaction, emotions (Macht \& Simons, 2000; Spinelli et al, 2014) and sociability (Danesi, 2012). Consequently, on a longer-term perspective, eating and drinking habits may contribute to feeling good in life in terms of physical, emotional and social aspects, thus contributing to general well-being (Diener et al., 2003; Lindert et al., 2015). The conceptualization of feeling good was investigated in a larger number of countries covering Africa, Asia, Australia, North and South America as well as Northern, Southern and Eastern Europe. To the best of our knowledge, no studies have previously investigated the dimensions that underlie the concept of feeling good in relation to food. In particular, the present study aimed to explore (i) consumer's associations with foods and feeling good, (ii) which foods and beverages are associated with feeling good, and (ii) cultural differences in those associations.

\section{Materials and Methods}

\subsection{Study Design}

\subsubsection{Consumers}

A total of 8,325 consumers from fourteen countries on five continents, speaking ten different languages, took part in this study: France, Germany, Italy, Norway, Poland, Spain, United Kingdom, Australia, Brazil, China, India, Russia, South Africa and the USA. Between 550 and 600 consumers were recruited in each country by an independent consumer research agency.

Sample size was intentionally predefined with quotas for age and gender. The gender distribution was set up at 300 males and 300 females in each country. Each gender was broken down into three subgroups based on age with a similar number of participants in each gender subgroup (i.e., 100): 18 to 25 years old, 26 to 45 years old and 46 to 65 years old. The characterization of participants is presented in Table 1. These quotas were achieved for all countries except Australia, Norway and South Africa. In these three countries, the quotas for younger males were below target (87, 50 and 89 instead of 100 , respectively). 
Consumers who worked in or had an immediate family working in, market research, advertising, cosmetic and personal care industry, home care industry, food and beverages industry, public relations and media, were excluded from participating in this study. Additionally, to ensure culturally representative answers, only those who declared that they had lived in their country for their whole life were selected. Participants were not told what the aim of the study was and were paid to participate.

\section{<insert Table 1 about here>}

\subsubsection{Data Collection}

A qualitative approach based on a combination of free association and free listing was used for data collection. Free association is a projective technique that encourages respondents to project their underlying motivations, beliefs, attitudes or feelings regarding a specific topic (Malhotra, 1993). Free listing is a qualitative technique extensively used in anthropology, which consists of asking participants to list all the items that fit into a specific criterion (Bernard, 2005; Hough and Ferraris, 2010).

The questionnaire comprised five main tasks: three free association tasks and two free listing tasks. The three free association tasks were used to explore consumers' general associations with feeling good (T1), feeling good related to food and beverage products (T2) and feeling bad related to food and beverage products (T5). Two free listing tasks were used to explore specific aspects of feeling good in the context of food and beverages. Task 3 (T3) aimed at exploring specific food and beverage products associated to feeling good at present and task 4 (T4) aimed at exploring ways in which food and beverages could make participants feel good in future situations. In each task, participants were asked to write down the first four words that came into their mind when thinking about each of the concepts. The specific wording of the tasks is presented in Table 2. Due to the extensive amount of data, this paper will only focus on tasks T2, T3 and T4.

\section{<insert Table 2 about here>}

The questionnaire was developed in English and translated into each language by two independent native speaking researchers. A final check was performed by a third native speaking researcher. Data were collected using a web-based questionnaire in all countries during February 2016. All consumers answered all the questions one at a time and once completed participants could not go back to previously answered questions. The order of the questions was fixed for all participants to minimize any potential bias by going from general to specific aspects of feeling good, followed by feeling bad. Duration of the questionnaire was on average 10 minutes.

\subsection{Data Analysis}

The data were analyzed using inductive coding based on the whole data set (Krippendorff, 2004). A coding frame was set up by a data analysis team consisting of three multilingual researchers of the project team, fluent in eight of the ten languages involved (all except Chinese and German). Native-speakers were recruited for each language (i.e., Chinese, English, French, German, Italian, Norwegian, Polish, Portuguese, Russian, Spanish) from among the European Sensory Network members to assign each individual word to a unique code according to the established coding 
frame (Table 3). All coders were fluent in English, securing a good understanding of the code frame categories. Coding was first performed individually by two native speakers and then discussed to reach a consensus. The coding was then thoroughly revised by the data analysis team to ensure that similar words or expressions were coded the same way across languages and all possible erroneous coding was corrected. As China results stood out from the other countries in the initial data analyses, a third Chinese native speaker was asked to review Chinese coding before running the data analysis displayed in the present paper. Non-answers, undecipherable or meaningless characters were coded as 'blank answer'. Codes were then sorted into categories and dimensions by the data analysis team with the input of native-speaker coders (Table 3 ). In the present paper, data analyses were restrained to category and dimension levels.

\section{<Insert Table 3 about here $>$}

For each category or dimension, the percentage of respondents who gave at least one answer assigned to this category or dimension was calculated. For a given respondent, duplicate answers, namely unique words that belong to the same category (or dimension) were counted only once. See below two examples:

- Example 1 - category score. A respondent answered: "apple, pear, grapes, green beans" to T3. The unique words 'apple', 'pear' and 'grapes' were assigned to the code 'Fruit'. The unique word 'Green beans' was assigned to the code 'Vegetables'. The codes 'Fruit' and 'Vegetables' were assigned to the category 'Fruits and vegetables'. The category 'fruits and vegetables' was assigned to the dimension 'Specific food \& beverages'. Therefore, this respondent scored 1 in the category 'Fruit and vegetables' and 1 in the dimension 'Specific food \& beverages'.

- Example 2 - percentage of mentions of the dimensions. Respondent $A$ answered "chocolate, strawberry, candy, Coca-Cola"; all these words belong to the dimension 'Specific food \& beverages', which gets a score of 1 for this respondent. Respondent B answered "cheese, wine, happy, relaxed", i.e. two words belong to the dimension 'Specific foods \& beverages' and two words to the dimension 'Emotion'; this leads to a score of 1 for each of these two categories. Respondent C answered "cake, happy, feast, romantic", i.e. one word belongs to the dimension 'Specific food \& beverages', two words to the dimension 'Emotion' and one word to the dimension 'Context'. Consequently, the percentage of mentions over these three respondents were $100 \%$ for 'Specific food \& beverages', $66 \%$ for 'Emotion' and 33\% for 'Context'.

According to this strategy, the percentage of mentions for a given category (or dimension) corresponds to the percentage of respondents who associated this category (or dimension) to feeling good rather than the percentage of answers associated with this category (or dimension). The percentage of 'no-answer' corresponds to the percentage of participants who provided 4 blank answers for a task.

Chi-squared tests were run at the 95\% confidence level on all contingency tables created. Only dimensions for which at least one country had a frequency count of at least $15 \%$ were included. 


\section{Results}

Overall the countries, 31,662, 31,799 and 29,183 valid (i.e. not blank) answers were collected for T2, T3 and T4, respectively. These answers were assigned to 150 unique codes which were themselves sorted in 81 categories and 8 dimensions (Body \& health: 10 categories; Context: 7 categories; Cooking \& eating: 5 categories; Emotion: 11 categories; Specific food \& beverages: 19 categories; Nutrition: 9 categories; Nonsensory properties: 13 categories; Sensory \& hedonic properties: 7 categories) (Annex 1).

\subsection{Association between food \& beverages and feeling good (Task 2)}

When participants were asked to write down the first four words that came to their mind when thinking about food/beverages and feeling good, $62 \%$ named at least one specific food or beverage (Table 4). The most frequently mentioned foods within this dimension were sweet and fat food (20\% of citations overall the countries), alcohol $(19 \%)$, fruit and vegetables (16\%), soft drink (15\%) or protein food (15\%) (Table 5).

The other most frequently used dimensions were sensory \& hedonic properties, mentioned by $34 \%$ of the participants, emotion (22\%), non-sensory properties (20\%), body \& health (19\%), nutrition (13\%) and context (11\%).

\section{<insert Table 4 about here>}

The most relevant category within the dimension sensory \& hedonic properties of foods was tastes good (e.g., delicious, appetizing, yummy). This category was mentioned by $24 \%$ of the participants across the countries. It was particularly relevant in China with $72 \%$ of citations, but also in Russia (30\%), India (29\%) and United-Kingdom (29\%). Interestingly, tastes good was also the most frequently first-mentioned category in these four countries (China: $25 \%$ of the first-mentioned words belong to the category tastes good; Russia: 22\%; India: 18\%; UK: 16\%). The other categories within the dimension sensory \& hedonic properties were mentioned by less than $10 \%$ of the participants across countries. Flavor (e.g., flavor, taste) and temperature (e.g., hot, warm, cold) were the most frequent categories (mentioned by $8 \%$ and $7 \%$ of the participants respectively).

Non-sensory properties were also salient in consumers' conceptualization of feeling good in the context of foods and beverages. This dimension comprised a large number of product characteristics with frequency of mention lower than $5 \%$. The most frequently mentioned categories within this dimension were natural (5\%), unspoiled $(4 \%)$, inexpensive (3\%), good quality $(3 \%)$, foreign food $(2 \%)$, home-made $(2 \%)$.

Participants mentioned effects of consuming foods and beverages, highlighting both emotional and health-related aspects. As shown in Table 4, the dimension emotion was more frequently mentioned than the dimensions body and health. Within the emotion dimension, participants mostly referred to positive emotions and feelings, including happy $(12 \%)$, enthusiastic $(6 \%)$, satisfied $(4 \%)$, peaceful $(3 \%)$ and entertained $(2 \%)$.

The dimension body and health included all references to the effect of foods and beverages on health and body functioning. The most frequent response within this 
dimension was related to general references to health, grouped in the category general health (e.g., healthy, health, preventing disease), which was mentioned by $8 \%$ of the participants. The other most frequent categories within this dimension were satiated $(6 \%)$, thirst $(4 \%)$, hungry $(3 \%)$, and active $(3 \%)$. In addition, participants also mentioned nutritional aspects of foods (dimension nutrition), mainly referring to the concept of healthy diet $(7 \%)$.

Contextual aspects of food and beverage consumption were also mentioned by participants in the word association task. The context dimension of food consumption was referred to through the category social (e.g., family, friends, social gathering; 6\%), as well as through specific situations where foods and beverages are consumed (eating out, 2\%; parties, $2 \%$; holiday, $1 \%$ ), or specific moments of the day (time, $2 \%$ ).

When looking at the difference between the countries, China stands out with few citations related to a specific food or beverage item and higher citations related to tastes good, happy and enthusiastic (Table 5) (e.g., filled with happiness and joy). Interestingly, several countries (Brazil, Germany, Norway, Poland, Spain, and to a lesser extent France) strongly associated feeling good with beverages such as alcohol, soft drink, water, hot drink, and/or fruit juice while others seldom made such an association (Australia, China, India). Seven countries (Brazil, France, Germany, Italy, Norway, Poland and Spain) strongly associated feeling good with water (percentage of mentions $>22 \%$ except for Poland: $17 \%$ ) while such an association was scarcely observed in the other countries (percentage of mentions ranging from 1 to $7 \%$ ). Six countries out of the former seven (Brazil, France, Germany, Italy, Norway and Spain) also strongly associated feeling good with fruit \& vegetables (percentage of mentions $>22 \%$ ). Among country peculiarities, we can note that Norway strongly associated feeling good with protein food (29\%); Brazil strongly associated feeling good with fruit juice (26\%); South Africa strongly associated feeling good with protein food and fast and street food; Poland and France associated feeling good with sweet \& fat food more than the other countries.

\section{<insert Table 5 about here>}

\subsection{Foods \& beverages that make you feel good (Task 3)}

As expected, $96 \%$ of respondents mentioned specific food or beverage items when asked to write down 'four foods or beverages that make you feel good' (Table 4). A small share of the responses was related to specific characteristics of foods and beverages instead of specific products.

Across the 14 countries, three food categories were associated with the highest percentage of mention: sweet \& fat food (e.g., cake, chocolate, ice cream; $34 \%$ of citations), fruit \& vegetables (e.g., fruit, vegetables, salad; $32 \%$ ) and protein food (e.g., red meat, white meat, fish, seafood, egg; $32 \%)$. They were followed by three beverage categories: alcohol (e.g., wine, beer, alcohol, spirits; 28\%), hot drink (e.g., coffee, tea, hot chocolate; 26\%) and soft drink (e.g., soda, lemonade, iced tea; 24\%) (Table 6).

When looking at the country level (Table 6), the categories sweet \& fat food and hot drink were markedly salient in Poland (53\% and $41 \%$ of overall citations; $24 \%$ and $20 \%$ of first-mentioned citations) as well as in Russia (50\% and $45 \%$ of overall citations; $21 \%$ and $21 \%$ of first-mentioned citations). In Norway and in South Africa, a strong 
association between feeling good and protein food was observed, with $55 \%$ of the Norwegian respondents mentioning at least one protein food in their answers $(18 \%$ for the first-mentioned word), and $53 \%$ of South African mentioning at least one protein food in their answers (16\% for the first mentioned word). A similar result was already observed for Task 2: $29 \%$ of the Norwegian and $28 \%$ of the South African already mentioned a protein food when thinking about food/beverages and feeling good (Table $6)$. The category starchy food was quite salient in Italy (41\% of the citations), India $(36 \%)$, Brazil (36\%) and Spain (35\%). The Brazilian consumers mainly associated feeling good with fruit and vegetables (37\%) and fruit juice (36\%) - 22\% of the Brazilian first-mentioned a fruit (including fruit juice) or a vegetable when answering task 3 . This was also observed for task 2 , with $50 \%$ of Brazilian respondents mentioning a fruit (including fruit juice) or a vegetable first when thinking about food/beverages and feeling good (Table 6).

Looking at water and alcohol, it is interesting to note that France, Germany, Italy and Norway associated feeling good with water more than the other countries, while Australia, Poland, Russia and the United-Kingdom associated feeling good with alcohol more than the other countries. In line with these results, $18 \%$ of French, $15 \%$ of German, $19 \%$ of Italian and $15 \%$ of Norwegian respondents first mentioned water when answering Task 2 , while $15 \%$ of Australian respondents first mentioned a product with alcohol.

\section{<insert Table 6 about here>}

\subsection{Association between food \& beverages and feeling good in the future (task 4)}

When asking the participants to list 'four ways in which foods and beverages will make you feel good in the future', 34\% of them mentioned at least one specific food or beverage item and $30 \%$ mentioned at least one term related to non-sensory properties. Participants most frequently mentioned foods and beverages positively associated with health (fruit \& vegetables $13 \%$, protidic food $8 \%$ ) than those generally negatively associated with health (sweet \& fat food $8 \%$, fast and street food $4 \%$ ). Regarding nonsensory properties of foods, participants mentioned a wide range of characteristics with similar frequency. The most relevant categories within this dimension were: natural $(9 \%)$, inexpensive $(6 \%)$, home-made $(5 \%)$, good quality $(5 \%)$, unspoiled $(4 \%)$ and convenient $(3 \%)$.

The dimensions body \& health, nutrition, sensory \& hedonic properties and emotion were also associated with feeling good in the future by $28 \%, 25 \%, 24 \%$ and $20 \%$ of the respondents, respectively (Table 4). The most relevant categories within these dimensions were similar to those reported in Section 3.1.

The association between healthy diet and feeling good in the future was higher in Australia (25\%), South Africa (26\%), the USA (22\%) and the United Kingdom (21\%) than in the other countries. This category was also the most frequent first-mentioned category in these four countries (Australia: 12\% of the first mentioned words belong to the category healthy diet; South Africa: 12\%; USA: 10\%; UK: 10\%). The association between fruit \& vegetables and feeling good in the future was higher in China $(35 \%)$, Brazil (33\%) and Germany (26\%). However, this category was the most frequently first mentioned category only in Germany with $10 \%$ of the first mentioned. 
By looking more closely at each country, a few peculiarities could be observed. In China, a quite strong association between feeling good in the future and the category protein food was observed, with $31 \%$ of the Chinese respondents mentioning at least one protein food in their answer (12\% for the first mentioned word). In Italy, a salient association between feeling good in the future and the category natural was observed, with $23 \%$ of the Italian respondents mentioning at least one word related to naturalness in their responses to the task ( $11 \%$ for the first mentioned word). Finally, a noticeable association between feeling good in the future and the category social was observed in Norway (24\%) and with the category water in Germany $(20 \%)$.

\section{<insert Table 7 about here>}

\section{Discussion}

\subsection{Conceptualization of feeling good in the context of foods and beverages across the countries}

Participants reported a wide range of associations when thinking about food and beverages and feeling good, which suggests the multi-dimensional nature of the construct. Interestingly, the most frequent associations with feeling good in the context of foods were related to specific foods or beverages (55\% to $77 \%$ of the participants in the 14 countries), rather than to an "abstract" concept. This suggests that the experience of consuming products makes consumers feel good and not necessarily their specific properties (sensory, hedonic, non-sensory, nutritional).

The importance of product experiences on consumers' conceptualization of feeling good was evidenced by the frequency of mention of categories related to hedonic experiences and emotional reactions to foods, such as tastes good and emotion. Interestingly, the most relevant emotional reported by Ares et al. (2015) when exploring consumers' conceptualization of well-being were similar to those referred to in the present work: pleasure, happiness, enthusiasm, satisfaction and peace/calm. Physical aspects were also relevant for participants' conceptualization of feeling good in the context of food and beverages. Participants referred to both the effects of foods on body functioning, as well as their general contribution to health and disease prevention.

However, it should be noted that health and nutrition-related aspects were more salient for consumers when they were asked to think about how foods and beverages would make them feel good in the future. Participants gave more relevance to physical and nutritional dimensions and less relevance to sensory and hedonic properties in Task 4 compared to Task 2. Looking at categories, $24 \%$ of the respondents mentioned a word related to "Tastes good" in task 2 against only $12 \%$ in task 4 . Conversely, $15 \%$ of the respondents mentioned a word related to "Healthy diet" in task 4 against $7 \%$ in task 2 . In other words, food-related feeling good seems to be mainly driven by sensorial pleasure at present, but by nutrition and health in the future. This result is in line with the fact that time perspectives have been reported to influence food choices. People who consider the future consequences of their decisions tend to select healthier products than those who are oriented towards obtaining immediate consequences (Dassen et al., 2015; De Marchi et al., 2016; Tórtora \& Ares, 2018). 
In the present work, health-related aspects were less frequently mentioned than emotional aspects of food consumption. This contradicts findings reported by Ares et al. (2015) in a similar word-association study on food and well-being. According to these authors, $76 \%$ of all citations were related to physical health, whereas only $22 \%$ of the citations were related to psychological aspects of well-being. Therefore, it can be concluded that people may give more relevance to physical health and healthy food when asked about food-related associations with well-being (Ares et al., 2015) than when asked about food-related associations with feeling good (present experiment). In fact, the increasing use of the term "well-being" in a medical context (Dodge et al., 2012; WHO, 2018) may lead the term "well-being" to prime health concepts (and in turn healthy food concepts).

The relevance of emotional over health-related aspects for consumers' conceptualization of feeling good has implications for the design of strategies for promoting healthy diets. Most interventions and communication campaigns have heavily relied on the concept of health and have not taken into account emotional and pleasurable aspects of food consumption, as stressed by Pettigrew (2016). Results from the present work suggest that using the concept of "feeling good" or making emphasis on positive feelings and emotions may be successful for encouraging changes in dietary patterns. Further research in this respect should be conducted.

\subsection{Foods and beverages associated with feeling good across the countries}

When participants were asked to list foods or beverages that made them feel good (task 3), almost all food dietary groups were represented through the categories associated with a percentage of mention higher than $10 \%$ overall the countries: protein food (meat, fish, seafood, eggs), fruit \& vegetables, starchy food (potatoes, rice, pasta, noodles), dairy product (milk, yogurt) and sweet \& fat food. Similarly, beverage categories associated with a percentage of mention higher than $10 \%$ included water, fruit juice, soft drink, hot drink and alcohol. In fact, there are no salient food or drink groups associated with feeling good, but it seems that each food or drink group may be related to feeling good. Interestingly, specific items associated with "feeling good" included both products recommended for a healthy diet (i.e., fruit and vegetables, water) as well as products for which consumption should be limited according to dietary guidelines (i.e., sweet \& fat food, soft drink). However, when consumers were asked to think about feeling good in the future, health-related aspects of food consumption were more salient, as evidenced by the increase in the frequency of mention of the category fruit \& vegetables.

\subsection{Differences between countries in the conceptualization of feeling good}

Although the general conceptualization of feeling good was similar across the countries, some differences were identified. This result agrees with the fact that culture is one of the main variables influencing our food choices, as well as attitudes and beliefs about food (Rozin, 1998). Differences between countries can also be related to language (Helms, 1992), as the way the expression "feeling good" is used by people in their everyday life may differ across languages.

In the present work, some of the differences between countries in the associations with feeling good in the context of food and beverages can be linked to the food habits 
and/or food surroundings of the countries. For instance, feeling good was strongly associated to fruit juice in Brazil $(26 \%)$, to rice in India (21\%), to pasta in Italy (33\%) and to fish \& seafood in Norway (29\%). However, it is worth stressing that differences between countries in food habits were not always evident in consumers' responses. For examples, some associations that could have been expected were not observed: feeling good was associated to tea by only $16 \%$ of the respondents in United Kingdom and to rice by only $7 \%$ of Chinese participants.

When looking at the associations elicited by participants when thinking of food and beverages and feeling good, it is interesting to note that European countries did not show a unique concept of feeling good, not even from the geographical poles usually considered in Europe (Northern versus Southern; Western versus Eastern). This result is in line with results from previous studies that stress the heterogeneity in food culture across Europe (e.g. Ares et al., 2016; Askegaard \& Madsen, 1998; Guerrero et al., 2010). United Kingdom stood somewhere apart from Europe by associating feeling good with "tastes good" more than participants in other European countries. By looking at Table 5, Spain displayed a "feeling good profile" somewhat closer to the one of Norway than to the one of Italy. In fact, both Spanish and Norwegian respondents strongly associated feeling good with alcohol, fruit \& vegetables, soft drinks, protein food and water, while Italian respondents associated feeling food with fruit \& vegetables and water, but not with soft drinks and protein food.

Finally, a striking result of the present experiment is that China clearly stood out from the other countries when participants wrote down the first four words that came to their mind when thinking of food and beverages and feeling good (task 2). This can be explained using the framework proposed by Hofstede (1980). The Asian culture, unlike the Western culture, is characterized by collectivism, i.e. people tend to view things in the larger context, to respect the opinion of the majority and to avoid confrontations (Hofstede, 2001). Previous research has reported differences in the value attached to food and eating between China and Western countries. Foods in China have a deeper meaning and are more strongly associated with social status, accomplishment and relationships than in Western countries (Ma, 2015). In the present work, Chinese people strongly associated feeling good with positive affects such as "tastes good", "happy" and "enthusiastic" rather than to specific foods or beverages item. In particular, the highest frequency of mention of the category "happy" was observed in China (Table 5). On the contrary, references to nutrition and healthy diet tended to be more frequent in Western countries. This difference can be related to the implementation of public policies and public campaigns to promote healthy diet, which are mainly based on nutrients (Pettigrew, 2016). For instance, the French National Nutrition Programme launched in 2007 requires health promotion messages to be included on all advertisements for food products (e.g. "Eat five fruit and vegetables per day" or "For your health, avoid eating too fatty, too sweet or too salty").

Despite differences in the ways foods are shared in China and Europe (Pearcey \& Zhan, 2018), in the present work the social dimension of foods was similarly mentioned in all countries. In China (as in India), a dish is placed in the middle of the table and everyone draws directly into the dish with his/her own cutlery (Ma, 2015). On the contrary, Western countries have a more individualistic approach to food and a dish is placed in the middle of the table and everyone takes a portion of the dish to put it on his/her own plate (Monin \& Szczurek, 2014). Further research is needed to investigate the possible relationship between feeling good and food environment (including public 
policy) as well as food practices and attitudes. To succeed, such research should involve sociologists in addition to food and consumers scientists. Such research should also sample the countries according to explicit variables related to food environment and/or food habits. Even if the present experiment was the very first one to explore food-related feeling good by encompassing a larger number of countries covering all the continents, European countries were overrepresented.

\section{Conclusions}

The present work aimed at presenting a cross-cultural perspective on feeling good in the context of foods and beverages in 14 countries across the globe. Results showed that feeling good is a multi-dimensional construct related to three main dimensions: emotional, physical (health-related aspects) and social. Clearly, sensory and hedonic aspects of food consumption were the most salient associations when people were asked to think about food and beverages and feeling good. However, results also showed that in the perspective of feeling good in the future, health gained salience in consumers' responses, thus increasing similarities to well-being. These results stress the importance of hedonic aspects of food consumption and stress the need to take them into account in the development of healthful products, as well as in the design of communication campaigns and interventions targeted at encouraging people to adopt healthier eating patterns.

Although general conclusions were similar across countries, cultural differences in the conceptualization of feeling good were found, as evidenced by differences in the frequency of mention of the categories. These differences were both related to food habits and to the value attached to foods. Further studies should aim at better understanding cultural differences in the conceptualization of feeling good in relation to food and beverages, which will be key to the development of successful global initiatives aimed at encouraging healthy dietary choices and contributing to well-being in the population.

\section{Acknowledgements}

The authors would like to acknowledge the European Sensory Network (ESN) who funded this study as well as ESN members and industry partners who contributed to the study design, coding, data analysis and discussions. In particular, the authors would like to acknowledge Nathalie Martin (CH), Riette de Kock (ZA), Sophie RaviotDerrien (FR) and David Lyon (UK) for their involvement in questionnaire design as well as Sylvia Abbà (IT), Marta Arroyo (ES), Elisabetta Bandelli (IT), Pam Beytes (UK), Lise Dreyfuss (FR), Klaus Duerrschmid (AT), Philippe Jeanbourquin (CH), Eliza Kostyra $(\mathrm{PL})$, Hilde Kraggerud (NO), Astrid Poelman (AU), María José Sánchez (ES), Doug Vort (US) and Sylwia Zakowska-Bieman (PL) for in-depth discussions on experimental and data analysis design. A special thanks to Carol Mosca who travelled from Brazil to China through Europe and brought interesting insights to the discussion. We acknowledge the support of Fabienne Hübener for making the graphical abstract a reality.

Finally, the authors would like to acknowledge the following ESN members and partners who participated in the Food \& Beverage data coding task: Klaus Duerrschmid 
(AT), Astrid Poelman (AU), Philippe Jeanbourquin ( $\mathrm{CH})$, María José Sánchez (ES), Marta Arroyo (ES), Lise Dreyfuss (FR), Silvia Abbà (IT), Elisabetta Bandelli (IT), Hilde Kraggerud (NO), Eliza Kostyra (PL), Sylwia Zakowska-Bieman (PL), Pam Beyts (UK), Doug Vort (US). We also acknowledge the contribution of the following to the coding task, from ESN members and their colleagues: Jess Heffernan (AU), Ine Van Aken (BE), Ana Carolina Mosca (BR), Levana Li (CN), Jingtian Li (CN), Paula Tarancón (ES), Laura Laguaa-Cruanes (ES), Mads Erling Pedersen (NO), Ida Mailen Kasbo (NO), Hanne Prøis Kristiansen (NO), Camille Jane Esmero Fredriksen (NO), Anna Piotrowska (PL), Krill Mikhailov (RU), Marina Orlova (RU), Robyn Perry (UK), Adri du Plessis (ZA), Alan Marwick (ZA), Dewald Uys (ZA), Hanriette Visser (ZA), Itumeleng Magabane (ZA), Joyce Chinyanga (ZA), Leandri de Kock (ZA), Lerato Moiloe (ZA), Mariette de Kock (ZA), Sin Mei Tan (ZA), Udisha Bassai (ZA).

\section{References}

Ares, G., de Saldamando, L., Giménez, A., Claret, A., Cunha, L.M., Guerrero, L., de Mourad, A.P., Oliveira, D.C.R., Symoneaux, R. and Deliza, R. (2015). Consumers' associations with well-being in a food-related context: A cross-cultural study. Food Quality and Preference, 40B, 304-315.

Ares, G., Giménez, A., Vidal, L., Zhou, Y., Krystallis, A., Tsalis, G., Symoneaux, R., Cunha, L.M., de Moura, A.M., Claret, A., Guerrero, L., Cardello, A.V., Wright, A., Jefferies, L., Lloyd, M., Denize Oliveira, D. and Deliza, R. (2016). Do we all perceive food-related well-being in the same way? Results from an exploratory cross-cultural study. Food Quality and Preference, 52, 62-73.

Askegaard, S., \& Madsen, T. K. (1998). The local and the global: Exploring traits of homogeneity and heterogeneity in European food cultures. International Business Review, 7, 549-568.

Aubert, A. (2017). Promoting Well-being: Theoretical and Practical Implications. Keynote Presentation at ESN Well-being Workshop, Berlin, October 2017.

Bech, P. (1993). Health-related quality of life rating scales. In: Bech, P. (Ed.). Rating Scales for Psychopathology, Health Status, and Quality of Life: A Compendium on Documentation in Accordance with the DSM-III-R and WHO Systems. New York: Springer-Verlag, 395-424.

Bernard, H.R (2005). Free listing. In H.R. Bernard (Ed.), Research methods in anthropology: Qualitative and quantitative approaches (4th Edition, pp. 301-311), Lanham, MD: AltaMira Press.

Bock, A-K., Maragkoudakis, P., Wollgast, J., Caldeira, S., Czimbalmos, A., Rzychon, M., Atzel, B. and Ulber, F. (2014). JRC Foresight Study: Joint Research Centre Tomorrow's Healthy Society Research Priorities for Foods and Diets. European Commission 
Danesi, G. (2012). Pleasures and stress of eating alone and eating together among French and German young adults. Menu: The Journal of Eating and Hospitality Research, 1, 77-91.

Dassen, F. C., Houben, K., \& Jansen, A. (2015). Time orientation and eating behavior: Unhealthy eaters consider immediate consequences, while healthy eaters focus on future health. Appetite, 91, 13-19.

De Marchi, E., Caputo, V., Nayga, R. M., Jr., \& Banterle, A. (2016). Time preferences and food choices: Evidence from a choice experiment. Food Policy, 62, 99-109.

Diener, E., Emmons, R.A., Larsen R,J, Griffin S (1985). The satisfaction with life scale. Journal of Personality Assessment, 49, 71-5.

Diener, E., Oishi, S. and Lucas, R.E. (2003). Personality, Culture and Subjective Wellbeing: Emotional and Cognitive Evaluations of Life. Annual Review of Psychology, 54, 403-25.

Diener, E., Napa Scollon, C.N. and Lucas, R.E. (2009). The Evolving Concept of Subjective Well-being: The Multifaceted Nature of Happiness. In: Diener E. (Eds) Assessing Well-being. Social Indicators Research Series, vol 39. Springer, Dordrecht.

Dodge, R., Daly, A., Huyton, J., and Sanders, L. (2012). The challenge of defining wellbeing. International Journal of Well-being, 2(3), 222-235.

EuroQol Group (1990). EuroQol - a new facility for the measurement of health-related quality of life. Health Policy, 16, 199-208.

EU (2014). EU Action Plan on Childhood Obesity 2014-2020. European Commission. https://ec.europa.eu/health//sites/health/files/nutrition_physical_activity/docs/childhoo dobesity_actionplan_2014_2020_en.pdf. (Last accessed July 2018)

FAO (2015). Sustainable development goals. Available at: http://www.fao.org/sustainable-development-goals/goals/goal-3/en/. (Last accessed July 2018)

Guillemin, I., Marrel, A., Arnould, B., Capuron, L., Dupuy, A., Ginon, E., et al. (2016). How French subjects describe well-being from food and eating habits? Development, item reduction and scoring definition of the Well-being related to Food Questionnaire (Well-BFQ@). Appetite, 96, 333-346.

Guerrero, L., Claret, A., Verbeke, W., Enderli, G., Zakowska-Biemans, S., Vanhonacker, F., et al. (2010). Perception of traditional food products in six European regions using free word association. Food Quality and Preference, 21, 225-233.

Helms, J. E. (1992). Why is there no study in cultural equivalence in standardized cognitive ability testing? American Psychologist, 47(9), 1083-1101.

Hettler, B. (1984). Wellness. Encouraging a lifetime pursuit of excellence. Health Values, 8, 13-17. 
Hofstede, G. (1980). Culture's consequences: International differences in work-related values. Beverly Hills, CA. Sage.

Hofstede, G. (2001). Cultures' Consequences (2nd edition) Thousand Oaks, CA. Sage.

Hough, G. and Ferraris, D. (2010). Free listing: A method to gain initial insight of a food category. Food Quality and Preference 21(3), 295-301.

King, S.C., Snow, J., Meiselman, H.L., Sainsbury, J., Carr, B.T., McCafferty, D., Serrano, D.,Gillette, M., Millard, L. and Li, Q. (2015). Development of a questionnaire to measure consumer wellness associated with foods: The WellSense Profile ${ }^{\mathrm{TM}}$. Food Quality and Preference, 39, 82-94.

Krippendorff, K. (2004). Content analysis. An introduction to its methodology (2nd ed.). Thousand Oaks, CA: Sage Publications.

Lindert, J.,Bain, P.A., Kubzansky, L.D. and Claudia Stein, C. (2015). Well-being measurement and the WHO health policy Health 2010: systematic review of measurement scales European Journal of Public Health, Vol. 25, No. 4, 731-740

Ma, G. S. (2015). Food, eating behavior, and culture in Chinese society. Journal of Ethnic Foods, 2, 195-199.

Malhotra, N. K. (1993). Marketing Research: An Applied Orientation, second edition. Prentice-Hall International, New Jersey

Macht, M., \& Simons, G. (2000). Emotions and eating in everyday life. Appetite, 35(1), 65-71.

Mezzich, J.E., Cohen, N.L., Ruiperez, M.A., Banzato, C.E. and Zapata-Vega, M.I. (2011). The Multicultural Quality of Life Index: presentation and validation. Journal of Evaluation in Clinical Practice, 17, 357-64.

Meiselman, H.L. (2016). Quality of life, well-being and wellness: Measuring subjective health for foods and other products. Food Quality and Preference, 54, 101-109.

Monin, B. and Szczurek, L. M. (2014). Food and culture. In Adam B. Cohen's (Ed.): Culture re-examined: Broadening our understanding of social and evolutionary influence (pp. 155-190). Washington, DC: American Psychological Association.

Pearcey, S.M. and Zhan, G.Q. (2018). A comparative study of American and Chinese college students' motives for food choice. Appetite, 123, 325-333.

Pettigrew (2016). Pleasure: An under-utilised ' $P$ ' in social marketing for healthy eating. Appetite, 104, 60-69.

Renner, B., Sproesser, G., Strohbach, S., and Schupp, H. T. (2012). Why we eat what we eat. The Eating Motivation Survey (TEMS). Appetite, 59(1), 117-128. 
Rozin, P. (1998). Cultural approaches to human food preferences. In J. E. Morley, M. B. Sterman, \& J. H. Walsh (Eds.), Nutritional modulation of neural function (pp. 137153). San Diego: Academic Press San Diego.

Spinelli, S., Masi, C., Dinnella, C., Zoboli, G. P., and Monteleone, E. (2014). How does it make you feel? A new approach to measuring emotions in food product experience. Food Quality and Preference, 37, 109-122.

Tórtora, G., Ares, G. (2018). Influence of time orientation on food choice: Case study with cookie labels. Food Research International, 106, 706-711.

Veenhoven, R. (2000). The Four Qualities of Life: Ordering Concepts and Measures of the Good Life. Journal of Happiness Studies, 1-1,1-39.

WHO (1997). WHOQOL. Measuring quality of life. The world Health Organization Quality of Life Instruments (The WHOQOL-100 and the WHOQOL-BREF). WHO/MSA/MNH/PSF/97.

WHO Regional Office for Europe. (2012). Measurement of and target-setting for wellbeing: An initiative by the WHO regional office for Europe. Copenhagen, Denmark: WHO.

WHO (2018). Better food and nutrition in Europe: a progress report monitoring policy implementation in the WHO European Region. Regional Office for Europe. 
Tables

Table 1. Socio-demographic characteristics of participants in the fourteen countries $(n=8,325)$

\begin{tabular}{|c|c|c|c|c|c|c|c|c|c|c|c|c|c|c|c|}
\hline & & $\begin{array}{l}\frac{\pi}{\bar{N}} \\
\stackrel{\frac{\pi}{2}}{\frac{0}{0}} \\
\frac{0}{2} \\
\frac{1}{4}\end{array}$ & $\begin{array}{l}\bar{N} \\
\frac{\bar{N}}{m}\end{array}$ & $\stackrel{\frac{\pi}{5}}{\frac{5}{0}}$ & $\begin{array}{l}\stackrel{0}{0} \\
\stackrel{ }{\frac{1}{2}} \\
\text { L }\end{array}$ & 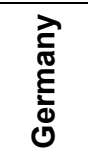 & $\stackrel{\frac{\pi}{\sigma}}{\underline{\underline{T}}}$ & $\underset{ \pm}{\frac{\pi}{\pi}}$ & $\begin{array}{l}\text { तो } \\
\text { zo } \\
z\end{array}$ & $\frac{\bar{C}}{\frac{0}{\pi}}$ & 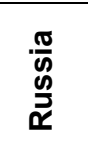 & 的 & $\begin{array}{l}\frac{5}{\pi} \\
\text { के }\end{array}$ & 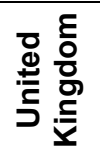 & ङ \\
\hline \multicolumn{2}{|c|}{ Number of participants } & 587 & 600 & 600 & 600 & 600 & 600 & 600 & 550 & 600 & 600 & 588 & 600 & 600 & 600 \\
\hline \multirow[t]{3}{*}{ Male } & $18-25$ yo & 87 & 100 & 100 & 100 & 100 & 100 & 100 & 50 & 100 & 100 & 89 & 100 & 100 & 100 \\
\hline & $26-45$ yo & 100 & 100 & 100 & 100 & 100 & 100 & 100 & 100 & 100 & 100 & 100 & 100 & 100 & 100 \\
\hline & $46-65$ yo & 100 & 100 & 100 & 100 & 100 & 100 & 100 & 100 & 100 & 100 & 99 & 100 & 100 & 100 \\
\hline \multirow[t]{3}{*}{ Female } & $18-25$ yo & 100 & 100 & 100 & 100 & 100 & 100 & 100 & 100 & 100 & 100 & 100 & 100 & 100 & 100 \\
\hline & $26-45$ yo & 100 & 100 & 100 & 100 & 100 & 100 & 100 & 100 & 100 & 100 & 100 & 100 & 100 & 100 \\
\hline & $46-65$ yo & 100 & 100 & 100 & 100 & 100 & 100 & 100 & 100 & 100 & 100 & 100 & 100 & 100 & 100 \\
\hline Partner / spouse & Yes & $52 \%$ & $62 \%$ & $72 \%$ & $63 \%$ & $59 \%$ & $64 \%$ & $53 \%$ & $53 \%$ & $59 \%$ & $62 \%$ & $59 \%$ & $57 \%$ & $57 \%$ & $61 \%$ \\
\hline Children & Yes & $46 \%$ & $57 \%$ & $61 \%$ & $50 \%$ & $42 \%$ & $55 \%$ & $44 \%$ & $48 \%$ & $56 \%$ & $61 \%$ & $60 \%$ & $41 \%$ & $45 \%$ & $54 \%$ \\
\hline \multirow[t]{7}{*}{ Daily activity } & Working full time & $35 \%$ & $60 \%$ & $78 \%$ & $52 \%$ & $52 \%$ & $54 \%$ & $43 \%$ & $47 \%$ & $52 \%$ & $58 \%$ & $56 \%$ & $45 \%$ & $48 \%$ & $47 \%$ \\
\hline & Working part time & $21 \%$ & $11 \%$ & $3 \%$ & $10 \%$ & $13 \%$ & $13 \%$ & $14 \%$ & $9 \%$ & $9 \%$ & $11 \%$ & $10 \%$ & $11 \%$ & $13 \%$ & $11 \%$ \\
\hline & Unpaid work & $11 \%$ & $5 \%$ & $1 \%$ & $5 \%$ & $6 \%$ & $10 \%$ & $8 \%$ & $2 \%$ & $4 \%$ & $8 \%$ & $7 \%$ & $4 \%$ & $10 \%$ & $11 \%$ \\
\hline & Unemployed & $8 \%$ & $8 \%$ & $1 \%$ & $9 \%$ & $6 \%$ & $6 \%$ & $12 \%$ & $7 \%$ & $10 \%$ & $5 \%$ & $7 \%$ & $15 \%$ & $8 \%$ & $9 \%$ \\
\hline & Retired & $12 \%$ & $5 \%$ & $8 \%$ & $8 \%$ & $8 \%$ & $3 \%$ & $3 \%$ & $8 \%$ & $9 \%$ & $6 \%$ & $5 \%$ & $4 \%$ & $10 \%$ & $8 \%$ \\
\hline & Full time student & $12 \%$ & $8 \%$ & $8 \%$ & $15 \%$ & $13 \%$ & $12 \%$ & $18 \%$ & $19 \%$ & $14 \%$ & $10 \%$ & $14 \%$ & $18 \%$ & $9 \%$ & $12 \%$ \\
\hline & Other / prefer not to state & $2 \%$ & $3 \%$ & $1 \%$ & $2 \%$ & $4 \%$ & $3 \%$ & $4 \%$ & $9 \%$ & $2 \%$ & $2 \%$ & $1 \%$ & $3 \%$ & $2 \%$ & $3 \%$ \\
\hline \multirow{5}{*}{$\begin{array}{l}\text { Highest education } \\
\text { level }\end{array}$} & Elementary school & $1 \%$ & $0 \%$ & $0 \%$ & $1 \%$ & $10 \%$ & $0 \%$ & $2 \%$ & $1 \%$ & $1 \%$ & $0 \%$ & $0 \%$ & $1 \%$ & $4 \%$ & $0 \%$ \\
\hline & High school & $42 \%$ & $3 \%$ & $6 \%$ & $6 \%$ & $40 \%$ & $5 \%$ & $8 \%$ & $10 \%$ & $2 \%$ & $7 \%$ & $38 \%$ & $11 \%$ & $27 \%$ & $35 \%$ \\
\hline & College & $19 \%$ & $40 \%$ & $26 \%$ & $37 \%$ & $29 \%$ & $10 \%$ & $57 \%$ & $40 \%$ & $51 \%$ & $23 \%$ & $29 \%$ & $41 \%$ & $32 \%$ & $33 \%$ \\
\hline & University, undergraduate degree & $29 \%$ & $45 \%$ & $60 \%$ & $41 \%$ & $12 \%$ & $46 \%$ & $27 \%$ & $38 \%$ & $17 \%$ & $13 \%$ & $27 \%$ & $36 \%$ & $31 \%$ & $23 \%$ \\
\hline & University, graduate degree & $8 \%$ & $12 \%$ & $8 \%$ & $16 \%$ & $9 \%$ & $39 \%$ & $6 \%$ & $12 \%$ & $29 \%$ & $57 \%$ & $5 \%$ & $12 \%$ & $8 \%$ & $9 \%$ \\
\hline
\end{tabular}


Table 2. Wording of the tasks of the online questionnaire related to feeling good in general and in the context of food and beverages.

\begin{tabular}{|c|l|c|}
\hline Task & Wording & Results \\
\hline T1 & $\begin{array}{l}\text { Write down the first four words that come to mind when thinking } \\
\text { about feeling good. }\end{array}$ & $\begin{array}{c}\text { Not reported in } \\
\text { the present paper }\end{array}$ \\
\hline T2 & $\begin{array}{l}\text { Write down the first four words that come to mind when thinking } \\
\text { about food and beverages and feeling good. }\end{array}$ & Tables 4 and 5 \\
\hline T3 & List four foods or beverages that make you feel good. & Tables 4 and 6 \\
\hline T4 & $\begin{array}{l}\text { List four ways in which foods and beverages will make you feel } \\
\text { good in the future. }\end{array}$ & Tables 4 and 7 \\
\hline T5 & $\begin{array}{l}\text { Write down the first four words that come to mind when thinking } \\
\text { about food and beverages and feeling bad. }\end{array}$ & $\begin{array}{c}\text { Not reported in } \\
\text { the present paper }\end{array}$ \\
\hline $\begin{array}{c}\text { Additional } \\
\text { questions }\end{array}$ & $\begin{array}{l}\text { Sociodemographic questions: marital status and children, daily } \\
\text { activity and education level. }\end{array}$ & \begin{tabular}{c} 
Table 1 \\
\hline
\end{tabular}
\end{tabular}


Table 3. Extract from the code frame used in the content analysis, illustrating an example of categories, codes and words within one of the dimensions.

\begin{tabular}{|c|c|c|c|}
\hline Dimension & Category & Code & Words \\
\hline \multirow{11}{*}{$\begin{array}{l}\text { Specific } \\
\text { food \& beverages }\end{array}$} & \multirow{5}{*}{ Sweet \& fat food } & Chocolate & $\begin{array}{l}\text { Chocolate, Cadbury@, Kit } \\
\text { Kat@, Snickers } \odot . . .\end{array}$ \\
\hline & & Pastry \& biscuits & $\begin{array}{l}\text { Cookies, cake, apple pie, } \\
\text { donuts, muffin... }\end{array}$ \\
\hline & & Sweet spreads & Honey, jam, Nutella $\odot . .$. \\
\hline & & Sweets & $\begin{array}{l}\text { Candy, jellybeans, } \\
\text { caramel, Smarties } \odot . . .\end{array}$ \\
\hline & & Ice-cream & Ice-cream, sorbet... \\
\hline & \multirow{3}{*}{ Fruit \& vegetables } & Fruit & $\begin{array}{l}\text { Fruit, apple, bananas, } \\
\text { cherries, mango... }\end{array}$ \\
\hline & & Vegetables & $\begin{array}{l}\text { Vegetables, tomatoes, } \\
\text { carrots, cauliflower... }\end{array}$ \\
\hline & & Soup & $\begin{array}{l}\text { Soup, home-made soup, } \\
\text { vegetables soup... }\end{array}$ \\
\hline & \multirow{3}{*}{ Protein food } & Red meat & $\begin{array}{l}\text { Beef, lamb, roast beef, } \\
\text { steak... }\end{array}$ \\
\hline & & Fish \& seafood & $\begin{array}{l}\text { Fish, seafood, lobster, } \\
\text { salmon, prawns... }\end{array}$ \\
\hline & & Eggs & $\begin{array}{l}\text { Egg, omelet, boiled egg, } \\
\text { scrambled egg... }\end{array}$ \\
\hline
\end{tabular}


Table 4. Percentage of mentions for each dimension when participants were asked to write down the first four words that come to their mind when thinking about food and beverages and feeling good (Task 2), to list four foods or beverages that made them feel good (Task 3), and to list four ways in which foods and beverages will make them feel good in the future (Task 4), across the 14 countries.

\begin{tabular}{|l|c|c|c|}
\hline Dimension & Task 2 & Task 3 & Task 4 \\
\hline Specific foods and beverages & $62 \%$ & $96 \%$ & $34 \%$ \\
\hline Sensory \& hedonic properties & $34 \%$ & $2 \%$ & $24 \%$ \\
\hline Emotion & $22 \%$ & $1 \%$ & $20 \%$ \\
\hline Non-sensory properties & $20 \%$ & $8 \%$ & $30 \%$ \\
\hline Body and health & $19 \%$ & $0 \%$ & $28 \%$ \\
\hline Nutrition & $13 \%$ & $2 \%$ & $25 \%$ \\
\hline Context & $11 \%$ & $1 \%$ & $15 \%$ \\
\hline Cooking and eating & $8 \%$ & $5 \%$ & $12 \%$ \\
\hline Other & $6 \%$ & $2 \%$ & $9 \%$ \\
\hline No answer & $3 \%$ & $3 \%$ & $9 \%$ \\
\hline
\end{tabular}


Table 5. Results of the word association task about food and beverages and feeling good (Task 2). For each category, percentage of mentions per country and overall the countries (last column). Only the categories associated with a percentage $\geq 15 \%$ in at least one country are displayed on the table. Percentage associated with a plus sign (+ in green) or a minus sign (- in orange) are respectively higher and lower than the overall percentage according to chi-square tests $(p<0.05)$.

\begin{tabular}{|c|c|c|c|c|c|c|c|c|c|c|c|c|c|c|c|c|}
\hline Dimension & Category & $\frac{\frac{\pi}{\pi}}{\stackrel{\frac{\pi}{2}}{\frac{5}{0}}}$ & $\begin{array}{l}\overline{\bar{N}} \\
\bar{\varpi} \\
\bar{\infty}\end{array}$ & : & 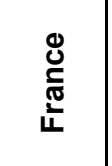 & 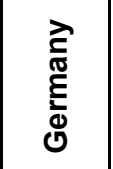 & $\stackrel{\frac{\sigma}{\sigma}}{\underline{\underline{g}}}$ & 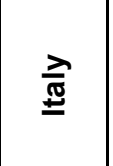 & $\begin{array}{l}\text { ते } \\
\frac{2}{2} \\
\mathbf{2}\end{array}$ & $\begin{array}{l}\text { 믐 } \\
\frac{0}{\pi} \\
0 \\
0\end{array}$ & 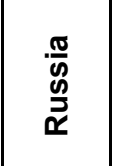 & 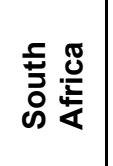 & 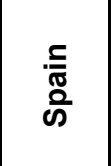 & 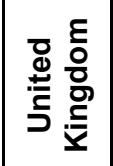 & 心 & $\begin{array}{c}\text { Overall } \\
\text { countries }\end{array}$ \\
\hline $\begin{array}{l}\text { Sensory \& hedonic } \\
\text { properties }\end{array}$ & Tastes good & 26 & $10(-)$ & $72(+)$ & $14(-)$ & $16(-)$ & $29(+)$ & $13(-)$ & $19(-)$ & $14(-)$ & $30(+)$ & 24 & $11(-)$ & $29(+)$ & 25 & $24 \%$ \\
\hline $\begin{array}{l}\text { Specific foods \& } \\
\text { beverages }\end{array}$ & Sweet \& fat food & 19 & 22 & $10(-)$ & $24(+)$ & 21 & 18 & 17 & $17(-)$ & $28(+)$ & 21 & 18 & 23 & 21 & 18 & $20 \%$ \\
\hline $\begin{array}{l}\text { Specific foods \& } \\
\text { beverages }\end{array}$ & Alcohol & 18 & 23 & $1(-)$ & 21 & $29(+)$ & $6(-)$ & 19 & $27(+)$ & $25(+)$ & 18 & 21 & $26(+)$ & $23(+)$ & 16 & $19 \%$ \\
\hline $\begin{array}{l}\text { Specific foods \& } \\
\text { beverages }\end{array}$ & Fruit \& vegetables & $12(-)$ & $24(+)$ & $3(-)$ & $25(+)$ & $22(+)$ & 14 & $23(+)$ & $23(+)$ & $13(-)$ & 18 & $11(-)$ & $23(+)$ & $11(-)$ & $9(-)$ & $16 \%$ \\
\hline $\begin{array}{l}\text { Specific foods \& } \\
\text { beverages }\end{array}$ & Soft drink & $9(-)$ & $20(+)$ & $4(-)$ & 14 & $21(+)$ & 12 & $10(-)$ & $23(+)$ & $21(+)$ & $9(-)$ & 17 & $26(+)$ & $7(-)$ & 16 & $15 \%$ \\
\hline $\begin{array}{l}\text { Specific foods \& } \\
\text { beverages }\end{array}$ & Protein food & 14 & 14 & $2(-)$ & $9(-)$ & 14 & $8(-)$ & 14 & $29(+)$ & $6(-)$ & $19(+)$ & $28(+)$ & $23(+)$ & 15 & 15 & $15 \%$ \\
\hline $\begin{array}{l}\text { Specific foods \& } \\
\text { beverages }\end{array}$ & Water & $7(-)$ & $23(+)$ & $1(-)$ & $23(+)$ & $24(+)$ & $2(-)$ & $22(+)$ & $25(+)$ & $17(+)$ & $3(-)$ & $4(-)$ & $25(+)$ & $3(-)$ & $7(-)$ & $13 \%$ \\
\hline $\begin{array}{l}\text { Specific foods \& } \\
\text { beverages }\end{array}$ & Fast and street food & 13 & 13 & $1(-)$ & $5(-)$ & $10(-)$ & $19(+)$ & 12 & 15 & $9(-)$ & $10(-)$ & $22(+)$ & 12 & 13 & $19(+)$ & $12 \%$ \\
\hline $\begin{array}{l}\text { Specific foods \& } \\
\text { beverages }\end{array}$ & Hot drink & 11 & $9(-)$ & $1(-)$ & $16(+)$ & $23(+)$ & 11 & 15 & $10(-)$ & $24(+)$ & 15 & $7(-)$ & $8(-)$ & 13 & $9(-)$ & $12 \%$ \\
\hline Emotion & Happy & $14(+)$ & $6(-)$ & $23(+)$ & 11 & $6(-)$ & $8(-)$ & $9(-)$ & $9(-)$ & 10 & $17(+)$ & 12 & $7(-)$ & $14(+)$ & 11 & $11 \%$ \\
\hline $\begin{array}{l}\text { Specific foods \& } \\
\text { beverages }\end{array}$ & Starchy food & $5(-)$ & $19(+)$ & $2(-)$ & $6(-)$ & $13(+)$ & 12 & $19(+)$ & 11 & $5(-)$ & $8(-)$ & 9 & $20(+)$ & $5(-)$ & 8 & $10 \%$ \\
\hline $\begin{array}{l}\text { Specific foods \& } \\
\text { beverages }\end{array}$ & Fruit juice & $2(-)$ & $26(+)$ & $2(-)$ & $11(+)$ & 9 & 10 & 7 & $6(-)$ & $16(+)$ & 10 & $6(-)$ & 10 & $3(-)$ & $5(-)$ & $9 \%$ \\
\hline Nutrition & Healthy diet & $5(-)$ & $16(+)$ & 6 & $9(+)$ & $3(-)$ & 7 & $11(+)$ & $10(+)$ & $5(-)$ & 7 & $3(-)$ & $11(+)$ & $3(-)$ & $3(-)$ & $7 \%$ \\
\hline Emotion & Enthusiastic & $7(+)$ & $2(-)$ & $17(+)$ & $2(-)$ & $2(-)$ & $11(+)$ & $2(-)$ & $1(-)$ & $2(-)$ & $3(-)$ & 6 & $3(-)$ & $9(+)$ & $12(+)$ & $6 \%$ \\
\hline
\end{tabular}


Table 6. Results of the free listing task in which participants mentioned food and beverages that make them feel good (Task 3). For each category, percentage of mentions per country and overall the countries (last column). Only the categories associated with a percentage $\geq 15 \%$ in at least one country are displayed on the table. Percentage associated with a plus sign (+ in green) or a minus sign (- in orange) are respectively higher and lower than the overall percentage according to chi-square tests $(p<0.05)$.

\begin{tabular}{|c|c|c|c|c|c|c|c|c|c|c|c|c|c|c|c|c|}
\hline Dimensions & Category & $\frac{\frac{\pi}{\bar{N}}}{\frac{\pi}{50}}$ & $\begin{array}{l}\overline{\bar{N}} \\
\frac{\pi}{\omega} \\
\bar{m}\end{array}$ & : & 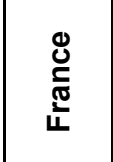 & 离 & $\stackrel{\frac{\pi}{0}}{\underline{\underline{C}}}$ & $\frac{\lambda}{\bar{\pi}}$ & $\begin{array}{l}\text { ते } \\
3 \\
2 \\
2\end{array}$ & $\begin{array}{l}\frac{0}{0} \\
\frac{\pi}{0} \\
0 \\
0\end{array}$ & 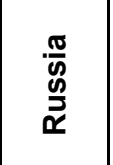 & 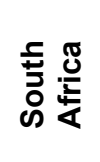 & 高 & 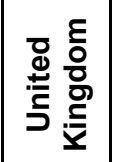 & હ & $\begin{array}{c}\text { Overall } \\
\text { countries }\end{array}$ \\
\hline $\begin{array}{l}\text { Specific foods \& } \\
\text { beverages }\end{array}$ & Sweet \& fat food & 36 & 33 & $20(-)$ & $39(+)$ & 31 & 30 & 34 & $19(-)$ & $53(+)$ & $50(+)$ & $30(-)$ & $30(-)$ & $39(+)$ & 29 & $34 \%$ \\
\hline $\begin{array}{l}\text { Specific foods \& } \\
\text { beverages }\end{array}$ & Fruit \& vegetables & 32 & 37 & $35(+)$ & $40(+)$ & $44(+)$ & $23(-)$ & 35 & 38 & $20(-)$ & 33 & $29(-)$ & 37 & $25(-)$ & $23(-)$ & $32 \%$ \\
\hline $\begin{array}{l}\text { Specific foods \& } \\
\text { beverages }\end{array}$ & Protein food & 35 & $29(-)$ & $39(+)$ & $23(-)$ & $24(-)$ & $19(-)$ & $23(-)$ & $55(+)$ & $9(-)$ & 32 & $53(+)$ & 36 & 32 & $36(+)$ & $32 \%$ \\
\hline $\begin{array}{l}\text { Specific foods \& } \\
\text { beverages }\end{array}$ & Alcohol & $37(+)$ & 26 & $11(-)$ & $23(-)$ & 28 & $12(-)$ & 32 & 31 & $35(+)$ & $37(+)$ & 31 & $36(+)$ & $35(+)$ & 24 & $28 \%$ \\
\hline $\begin{array}{l}\text { Specific foods \& } \\
\text { beverages }\end{array}$ & Hot drink & 29 & $15(-)$ & $16(-)$ & $30(+)$ & $33(+)$ & 25 & 28 & $18(-)$ & $41(+)$ & $45(+)$ & $19(-)$ & $13(-)$ & 28 & 21 & $26 \%$ \\
\hline $\begin{array}{l}\text { Specific foods \& } \\
\text { beverages }\end{array}$ & Soft drink & 20 & $22(-)$ & $30(+)$ & 21 & 23 & $18(-)$ & $20(-)$ & 26 & $32(+)$ & $14(-)$ & $31(+)$ & 27 & $18(-)$ & $35(+)$ & $24 \%$ \\
\hline $\begin{array}{l}\text { Specific foods \& } \\
\text { beverages }\end{array}$ & Starchy food & $18(-)$ & $36(+)$ & 18 & $15(-)$ & 21 & $36(+)$ & $41(+)$ & $18(-)$ & $5(-)$ & $8(-)$ & 23 & $35(+)$ & $17(-)$ & 23 & $22 \%$ \\
\hline $\begin{array}{l}\text { Specific foods \& } \\
\text { beverages }\end{array}$ & Water & 18 & 25 & $5(-)$ & $33(+)$ & $33(+)$ & $4(-)$ & $36(+)$ & $33(+)$ & 21 & $8(-)$ & $13(-)$ & $34(+)$ & $7(-)$ & $16(-)$ & $20 \%$ \\
\hline $\begin{array}{l}\text { Specific foods \& } \\
\text { beverages }\end{array}$ & Fast and street food & 20 & $16(-)$ & $12(-)$ & $8(-)$ & $15(-)$ & $31(+)$ & $26(+)$ & 18 & $12(-)$ & $13(-)$ & $36(+)$ & $16(-)$ & $25(+)$ & $32(+)$ & $20 \%$ \\
\hline $\begin{array}{l}\text { Specific foods \& } \\
\text { beverages }\end{array}$ & Fruit juice & $10(-)$ & $36(+)$ & 16 & 16 & $13(-)$ & $26(+)$ & 18 & $13(-)$ & $24(+)$ & $25(+)$ & 16 & 16 & $8(-)$ & $9(-)$ & $17 \%$ \\
\hline $\begin{array}{l}\text { Specific foods \& } \\
\text { beverages }\end{array}$ & Dairy & 12 & 16 & $17(+)$ & 15 & $18(+)$ & $16(+)$ & $8(-)$ & 13 & $11(-)$ & $17(+)$ & $10(-)$ & 13 & 10 & 11 & $13 \%$ \\
\hline $\begin{array}{l}\text { Specific foods \& } \\
\text { beverages }\end{array}$ & Salt \& fat food & $9(+)$ & $3(-)$ & 7 & 6 & 6 & 6 & $3(-)$ & 6 & $4(-)$ & 6 & 9 & $4(-)$ & $18(+)$ & 8 & $7 \%$ \\
\hline
\end{tabular}


Table 7. Results of the free listing task in which participants mentioned the ways food and beverages will make them feel good in the future (Task 4). For each category, percentage of mentions per country and overall the countries (last column). Only the categories associated with a percentage $\geq 15 \%$ in at least one country are displayed on the table. Percentage associated with a plus sign (+ in green) or a minus sign (- in orange) are respectively higher and lower than the overall percentage according to chi-square tests $(p<0.05)$.

\begin{tabular}{|c|c|c|c|c|c|c|c|c|c|c|c|c|c|c|c|c|}
\hline Dimensions & Category & 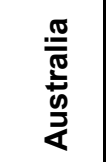 & $\begin{array}{l}\overline{\bar{N}} \\
\bar{\Phi} \\
\bar{m}\end{array}$ & $\frac{\mathbb{\pi}}{\frac{.}{C}}$ & $\begin{array}{l}\stackrel{\Xi}{0} \\
\stackrel{\frac{\pi}{\pi}}{4}\end{array}$ & $\begin{array}{l}\text { टे } \\
\text { है } \\
\stackrel{5}{0} \\
0\end{array}$ & $\stackrel{\underline{\pi}}{\underline{0}}$ & $\frac{\lambda}{ \pm}$ & $\begin{array}{l}\text { ते } \\
\text { 之o } \\
\mathbf{2}\end{array}$ & 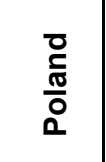 & 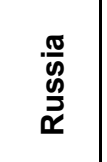 & 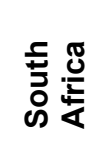 & $\begin{array}{l}\frac{5}{\sqrt{\pi}} \\
\text { ஸे }\end{array}$ & 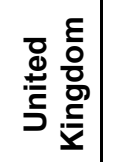 & હ & $\begin{array}{l}\text { Overall } \\
\text { countries }\end{array}$ \\
\hline Nutrition & Healthy diet & $25(+)$ & 13 & $2(-)$ & 15 & $9(-)$ & 19 & $17(+)$ & $11(-)$ & $7(-)$ & $11(-)$ & $26(+)$ & $9(-)$ & $21(+)$ & $22(+)$ & $15 \%$ \\
\hline $\begin{array}{l}\text { Specific foods \& } \\
\text { beverages }\end{array}$ & Fruit \& vegetables & $6(-)$ & $33(+)$ & $35(+)$ & $9(-)$ & $26(+)$ & 13 & $6(-)$ & 14 & $5(-)$ & $4(-)$ & $5(-)$ & 14 & $6(-)$ & $4(-)$ & $13 \%$ \\
\hline $\begin{array}{l}\text { Sensory \& hedonic } \\
\text { properties }\end{array}$ & Tastes good & $16(+)$ & $2(-)$ & $2(-)$ & 13 & $6(-)$ & $17(+)$ & $16(+)$ & 11 & 14 & $17(+)$ & 15 & $9(-)$ & $19(+)$ & 14 & $12 \%$ \\
\hline Body \& health & General health & 10 & $26(+)$ & $1(-)$ & $14(+)$ & $6(-)$ & $6(-)$ & $19(+)$ & $7(-)$ & $3(-)$ & $1(-)$ & 11 & $13(+)$ & 11 & 12 & $10 \%$ \\
\hline Emotion & Happy & $14(+)$ & 8 & $0(-)$ & $11(+)$ & $4(-)$ & 9 & 11 & $7(-)$ & $6(-)$ & $7(-)$ & $16(+)$ & $5(-)$ & $18(+)$ & $18(+)$ & $10 \%$ \\
\hline Body \& health & Satiated & $16(+)$ & $3(-)$ & $0(-)$ & 9 & $2(-)$ & $5(-)$ & 9 & 8 & $4(-)$ & $12(+)$ & $17(+)$ & $3(-)$ & $15(+)$ & $24(+)$ & $9 \%$ \\
\hline Non-sensory properties & Natural & $4(-)$ & $18(+)$ & $4(-)$ & $17(+)$ & $7(-)$ & 11 & $23(+)$ & $5(-)$ & 8 & $4(-)$ & $7(-)$ & $11(+)$ & $2(-)$ & $6(-)$ & $9 \%$ \\
\hline Context & Social & 12 & $2(-)$ & $1(-)$ & 7 & $6(-)$ & $6(-)$ & $6(-)$ & $24(+)$ & 7 & $18(+)$ & $15(+)$ & 9 & 11 & 8 & $9 \%$ \\
\hline Body \& health & Active & $16(+)$ & $12(+)$ & $0(-)$ & 8 & $5(-)$ & 8 & $5(-)$ & 9 & 10 & $6(-)$ & $14(+)$ & 7 & $13(+)$ & $15(+)$ & $9 \%$ \\
\hline $\begin{array}{l}\text { Specific foods \& } \\
\text { beverages }\end{array}$ & Protein food & $4(-)$ & 8 & $31(+)$ & $2(-)$ & $10(+)$ & 7 & $3(-)$ & $16(+)$ & $1(-)$ & $3(-)$ & 7 & $10(+)$ & $4(-)$ & $5(-)$ & $8 \%$ \\
\hline $\begin{array}{l}\text { Specific foods \& } \\
\text { beverages }\end{array}$ & Sweet \& fat food & $5(-)$ & $5(-)$ & $18(+)$ & $3(-)$ & $14(+)$ & 10 & 6 & $4(-)$ & $14(+)$ & $5(-)$ & $6(-)$ & 6 & 5 & 6 & $8 \%$ \\
\hline $\begin{array}{l}\text { Specific foods \& } \\
\text { beverages }\end{array}$ & Water & $3(-)$ & $15(+)$ & $4(-)$ & $9(+)$ & $20(+)$ & $2(-)$ & 7 & $15(+)$ & 5 & $0(-)$ & $3(-)$ & 7 & $2(-)$ & $4(-)$ & $7 \%$ \\
\hline $\begin{array}{l}\text { Specific foods \& } \\
\text { beverages }\end{array}$ & Alcohol & $4(-)$ & 6 & $13(+)$ & 5 & $15(+)$ & $4(-)$ & 5 & 9 & $10(+)$ & 6 & $6(-)$ & 8 & 5 & $4(-)$ & $7 \%$ \\
\hline $\begin{array}{l}\text { Specific foods \& } \\
\text { beverages }\end{array}$ & Hot drink & $3(-)$ & 6 & $15(+)$ & $4(-)$ & $17(+)$ & 6 & $4(-)$ & 5 & $12(+)$ & 5 & $3(-)$ & $2(-)$ & $4(-)$ & $3(-)$ & $6 \%$ \\
\hline Nutrition & Light product & 6 & $11(+)$ & $2(-)$ & $8(+)$ & 4 & 6 & $17(+)$ & $3(-)$ & $4(-)$ & $2(-)$ & $5(-)$ & $9(+)$ & 5 & 5 & $6 \%$ \\
\hline $\begin{array}{l}\text { Non sensory \& hedonic } \\
\text { properties }\end{array}$ & Unexpansive & 8 & $2(-)$ & $1(-)$ & 4 & $4(-)$ & 8 & $3(-)$ & $3(-)$ & $15(+)$ & $10(+)$ & $16(+)$ & 5 & 7 & $5(-)$ & $6 \%$ \\
\hline Cooking \& eating & Food / eating & 5 & $2(-)$ & $2(-)$ & $2(-)$ & $3(-)$ & $3(-)$ & 4 & 5 & $7(+)$ & $18(+)$ & 4 & 6 & 5 & 5 & $5 \%$ \\
\hline $\begin{array}{l}\text { Specific foods \& } \\
\text { beverages }\end{array}$ & Soft drink & $2(-)$ & 4 & $15(+)$ & 3 & $11(+)$ & 4 & $2(-)$ & $7(+)$ & $6(+)$ & $1(-)$ & $3(-)$ & 3 & $2(-)$ & $3(-)$ & $5 \%$ \\
\hline
\end{tabular}


Specific foods \&

beverages

Specific foods \&

Dairy

\begin{tabular}{|l|l|}
\hline $1(-)$ & 8 \\
\hline $1(-)$ &
\end{tabular}

\begin{tabular}{|c|c|c|c|c|c|}
$8(+)$ & $15(+)$ & $2(-)$ & $8(+)$ & 6 \\
\hline $2(-)$ & $15(+)$ & 3 & $6(+)$ & 10
\end{tabular}

\begin{tabular}{|c|c|c|c|}
\hline & $1(-)$ & 5 & 2( \\
\hline+$)$ & 4 & 3 &
\end{tabular}

\begin{tabular}{|c|c|}
\hline $2(-)$ & 1 \\
\hline 4 & 1 \\
\hline
\end{tabular}

\begin{tabular}{|l|l|l|l}
\hline & $1(-)$ & $2(-)$ \\
\hline $1(-)$ & $2(-)$ & \\
\hline
\end{tabular}

\begin{tabular}{|l|l|}
\hline 3 \\
\hline 4
\end{tabular}

\begin{tabular}{|c|c|c|}
\hline 3 & $2(-)$ & $4 \%$ \\
\hline $1(-)$ & $2(-)$ & $4 \%$ \\
\hline
\end{tabular}


Annex 1. List of dimensions, categories and codes

\begin{tabular}{|c|c|c|}
\hline Dimension & Category & Example of codes \\
\hline \multirow{19}{*}{$\begin{array}{l}\text { Specific food \& } \\
\text { drink }\end{array}$} & Fruit \& vegetables & Fruit, vegetables, salad \\
\hline & Protein food & Red meat, white meat, fish \& seafood, egg \\
\hline & Starchy food & Bread, past, rice, potatoes \\
\hline & Dairy product & Milk, yoghurt, cheese, cream \\
\hline & Sweet \& fat food & Cake, chocolate, ice cream, sweet spreads \\
\hline & Salt \& fat food & Chips, French fries, peanuts \\
\hline & Fast \& street food & Sandwiches, kebab, burger, hot dog \\
\hline & Snacks & Snacks \\
\hline & Breakfast cereal & Muesli, cereals, corn-flakes, oat, porridge \\
\hline & Seasoning & Herbs, spice, curry \\
\hline & Soy products & Soy, soy products \\
\hline & Water & Water, mineral water \\
\hline & Fruit juice & Fruit juice, orange juice, apple juice \\
\hline & Hot drink & Coffee, tea, hot chocolate \\
\hline & Soft drink & Soda, lemonade, iced tea \\
\hline & Alcohol & Wine, beer, alcohol, spirits \\
\hline & Energy drink & Energy drink, sport drink \\
\hline & No alcohol & No alcohol \\
\hline & Other food & Butter, gravy, sauce, finger food, chutney \\
\hline \multirow{5}{*}{ Cooking \& eating } & Food \& eating & Food, meal, eating \\
\hline & Drink \& drinking & Drink, drinking \\
\hline & Shopping & Shopping, food shop, supermarket \\
\hline & Cooking process & Barbecue, roasted, fried, steamed \\
\hline & Well-cooked & Well-cooked \\
\hline \multirow{7}{*}{ Context } & Social & Family, friends, social gathering, sharing... \\
\hline & Eating out & Eating out, restaurant, bar \\
\hline & Parties & Festivity, parties, celebration \\
\hline & \begin{tabular}{|l|} 
Leisure \\
\end{tabular} & Movies, playing \\
\hline & Holiday & Vacations, travel, on the road, off-days \\
\hline & Summer & Summer, sunshine, beach \\
\hline & Time & Time, breakfast, lunch, dinner \\
\hline \multirow{11}{*}{ Emotion } & Happy & Happy, enjoying, joy, glad, contentment \\
\hline & Enthusiastic & Enthusiastic, awesome, great \\
\hline & Entertained & Entertained, fun, interesting \\
\hline & Peaceful & Peaceful, relaxed, calm, tranquility \\
\hline & Love & Love \\
\hline & Craving \& reward & Craving, addition, reward \\
\hline & Satisfied & Satisfied, satisfaction \\
\hline & Comforted & Comfort, comfortable \\
\hline & Grateful & Grateful, thankful, blessed \\
\hline & Not guilty & Not guilty \\
\hline & Guilty & Guilty \\
\hline
\end{tabular}




\begin{tabular}{|c|c|c|}
\hline Dimension & Category & Example of answers \\
\hline \multirow{7}{*}{$\begin{array}{l}\text { Sensory \& hedonic } \\
\text { properties }\end{array}$} & Taste good & Taste good, yummy, delicious, eating good food \\
\hline & Flavor & Flavor, taste \\
\hline & Aroma & Aroma, scent, smell \\
\hline & Texture & Texture, soft, crispy, crunchy \\
\hline & Appearance & Appearance, colorful, presentation, looks good \\
\hline & Temperature & Hot, warm, cold, chilled \\
\hline & Spicy & Spicy, adequately spiced \\
\hline \multirow{13}{*}{$\begin{array}{l}\text { Non-sensory } \\
\text { properties }\end{array}$} & Natural & Natural, without additives, no GMO, organic \\
\hline & Price & Price, cost, money, cheap, expensive \\
\hline & Unspoiled & Unspoiled, fresh \\
\hline & Clean & Clean, hygienic \\
\hline & Quality & Quality, good quality \\
\hline & Home-made & Home-made, home-cooked \\
\hline & Convenient & Convenient, easy to prepare, ready-to-eat \\
\hline & New & New, innovative, adventurous \\
\hline & Raw & Raw \\
\hline & Foreign food & Exotic food, Asian, Italian, Chinese \\
\hline & Local & Local, authentic, regional products \\
\hline & Available & Available \\
\hline & Brand & Heinz@, Nestlé@, Knorr@ \\
\hline \multirow{9}{*}{ Nutrition } & Healthy diet & Healthy diet, healthy food, healthy eating, balanced \\
\hline & Unhealthy diet & Unhealthy diet \\
\hline & Quantity & Moderation, restraint, abundance, portion \\
\hline & Variety & Variety, eating different food \\
\hline & Light & Low calorie, fat free, less calorie, sugar free \\
\hline & Protein & Protein, rich in proteins \\
\hline & Sugar & Sugar \\
\hline & Vitamin & Vitamins, rich in vitamins \\
\hline & Vegetarian & Vegetarian, plant-based \\
\hline \multirow{10}{*}{ Body \& health } & General health & Health, healthy, preventing disease \\
\hline & Systemic health & Immunity, skin, bones \\
\hline & Mental health & Mental health \\
\hline & Hungry & Hungry, hunger \\
\hline & Thirst & Thirst, quenching thirst \\
\hline & Satiated & Full, filling \\
\hline & Digestion & Digestion, digesting \\
\hline & Need & Need, necessary, needed \\
\hline & Active & Energy, vital, active \\
\hline & Alcohol abuse & Being drunk \\
\hline
\end{tabular}




\section{Contributions by Author}

Claire Sulmont-Rossé - study design, data analysis, interpretation and publication.

Rafal Drabek - data analysis, interpretation and publication.

Valérie L. Almli - study design, data analysis, interpretation and publication.

Hannelize van $Z y l$ - study design and interpretation.

Ana Patricia Silva - study design and publication.

Martin Kern - study design and publication.

Jean A McEwan - publication.

Gastón Ares - study design, data analysis, interpretation and publication. 